\title{
PERBEDAAN BADAN HUKUM PUBLIK DAN BADAN HUKUM PRIVAT
}

\author{
A.A. Gede D. H. Santosa
}

Fakultas Hukum

Universitas Udayana

Email : gianyarsantosa@yahoo.com

\begin{abstract}
ABSTRAK
Berdasarkan Pasal 1 ayat (1) dan Pasal 2 NBW yang dimaksudkan dengan badan hukum publik itu adalah Negara, provinsi, kotapraja-kotapraja (kabupaten/kota), The Waterboards dan lembaga lembaga lainnya yang diberi wewenang dalam bidang legislatif (membuat dan mengeluarkan Peraturan Perundang-undangan) berdasarkan Undang-Undang Dasar Belanda. Badanbadan yang juga dapat disebut badan hukum publik adalah badan-badan selain yang disebutkan dalam Pasal 1 yang diberi wewenang dalam rangka tugastugas Pemerintah dan hasil yang menjadi tujuan pemberian wewenang tersebut secara spesifik ditentukan atau sesuai dengan hukum. Dengan demikian kriteria yang digunakan untuk menentukan suatu badan sebagai badan hukum publik adalah adanya kewenangan legislatif yang dimiliki badan itu berdasarkan Undang-Undang Dasar Belanda atau badan yang badan tertentu lainnya yang mempunyai atau diberi wewenang dalam rangka melaksanakan tugas-tugas Pemerintahan. Sementara itu badan hukum privat dalam NBW di atur dalam Pasal 3 Private Legal Persons disebutkan "Associations, Cooperatives, Mutual Insurance Societes, Open Corporations, Cloesed Corporation and Foundations have legal personality", badan-badan yang termasuk yang termasuk sebagai badan hukum privat adalah Perkumpulan/Perhimpunan, Perseroan Terbatas, Perusahan Asuransi Swasta, PT. Terbuka/Public Limited Company, PT. Tertutup/Private Limited Company dan Yayasan. Dengan demikian maka kriteria yang digunakan untuk menentukan suatu badan hukum merupakan badan hukum privat berdasarkan bentuk badan hukum itu, bentuk-bentuk badan hukum ini adalah badan hukum yang lazimnya mempunyai tujuan tertentu seperti mencari keuntungan atau tujuan sosial berkedudukan sama seperti orang perorangan yang tidak mempunyai kewenangan seperti badan hukum publik.
\end{abstract}

Kata kunci : Badan Hukum Publik, Badan Hukum Privat, Badan Hukum

\begin{abstract}
Based on Article 1 paragraph (1) and Article 2 NBW which are intended by public legal entities, they are the State, provinces, municipalities (regencies / cities), The Waterboards and other institutions authorized in the legislative field (making and issuing Legislation Regulations laws) based on the Dutch Constitution. Bodies which can also be called public legal entities are bodies other than those mentioned in Article 1 which are authorized in the framework of Government tasks and the results of which are given the specific authority are determined or in accordance with the law. Thus the criteria used to determine a body as a public legal entity is the existence of legislative authority possessed by that body based on the Dutch Constitution or other body which has or is authorized to carry out the tasks of the Government. Meanwhile private legal entities in NBW are regulated in Article 3 of the Persons Private Legal mentioned "Associations, Cooperatives, Mutual Insurance Societes, Open Corporations, Cloaked
\end{abstract}


Corporation and Foundations have legal personality", bodies including those included as private legal entities are Associations / Association, Limited Liability Company, Private Insurance Company, PT. Open / Public Limited Company, PT. Closed / Private Limited Company and Foundation. Thus, the criteria used to determine a legal entity is a private legal entity based on the form of a legal entity. These legal entities are legal entities which usually have certain objectives such as seeking a social advantage or purpose as individuals who have no authority. like a public legal entity.

Keywords: Public Legal Entity, Private Legal Entity, Legal Entity

\section{Pendahuluan}

Istilah badan hukum sudah lazim diketahui dan digunakan dalam pergaulan di masyarakat termasuk dalam berbagai lalu lintas hukum. Badan hukum merupakan subyek hukum selain manusia sebagai subyek hukum. Dalam bahasa Belanda badan hukum sebagai subyek hukum merupakan terjemahan dari rechtspersoon untuk manusia sebagai subyek hukum terjemahan dari natuurlijke persoon, sementara itu dalam literatur bahasa Inggris badan hukum sebagai subyek hukum dalam disebut legal person sedangkan natural person diterjemahkan sebagai manusia sebagai subyek hukum.

Para sarjana hukum menyebutkan beberapa istilah untuk menggantikan istilah badan hukum. Purnadi Purbacaraka dan Soerjono Soekanto menggunakan istilah pribadi hukum untuk menyebut badan hukum dan pribadi kodrati untuk manusia (Soekanto,1979). Sementara L.J. van Apeldoorn (1996) mengunakan istilah purusa hukum untuk badan hukum dan purusa kodrati untuk manusia. Malikul Adil sebagaimana yang dikutip Chidir Ali (2014) menyebut istilah badan hukum sebagai awak hukum dan awak orang untuk manusia.

Istilah badan hukum dapat ditemukan dalam berbagai Peraturan Perundang-undangan yang pernah berlaku dan masih berlaku sampai saat ini sehingga istilah badan hukum merupakan istilah yang resmi. Adapun Peraturan Perundang-undangan yang menyebutkan istilah badan hukum antara lain diantaranya Perpu Nomor 19 tahun 1960 tentang Perusahaan Negara, UndangUndang Nomor 40 tahun 2007 tentang Perseroan Terbatas, Undang-Undang Nomor 16 Tahun 2001 tentang Yayasan dan Perubahannya Undang-Undang Nomor 28 Tahun 2004, UndangUndang Nomor 25 Tahun 1992 tentang Perkoperasian, UndangUndang Nomor 5 Tahun 1960 tentang Peraturan Dasar Pokok Agraria, Undang-Undang Nomor 24 Tahun 2003 tentang Mahkamah Konstitusi.

Menjadi istilah resmi yang dapat ditemukan dalam berbagai Peraturan Perundang-undangan bukan berarti kita dapat menemukan batasan atau definisi tentang badan hukum. Dalam Kitab Undang-Undang Hukum Perdata (selanjutnya disebut KUHPerdata) kata rechtspersoon (badan hukum) sama sekali tidak terdapat dalam KUHPerdata. Menurut R. Ali Rido satu-satunya peraturan yang merupakan ketentuan umum mengenai badan hukum ialah Bab Kesembilan Buku Ketiga KUHPerdata yaitu Pasal 1653 tentang Zedelijk lichmen atau badan badan hukum susila (Rido, 2004). Pasal $1653 \quad$ KUHPerdata 
menyebutkan: "selainnya perseroan yang sejati oleh undang-undang diakui pula perhimpunanperhimpunan orang sebagai perkumpulan-perkumpulan, baik perkumpulan-perkumpulan itu yang diadakan atau diakui sebagai demikian oleh kekuasaan umum maupun perkumpulanperkumpulan itu diterima sebagai diperbolehkan atau telah didirikan untuk suatu maksud tertentu yang tidak bertentangan dengan undangundang dan kesusilaan".

Ketentuan Pasal 1653

KUHPerdata dan pasal-pasal berikutnya dari Bab Kesembilan Buku Ketiga KUHPerdata tidak memberikan suatu pengertian definisi dan batasan yang jelas dan tegas tentang apakah yang dimaksud dengan badan hukum, untuk itu dapat dilihat pengertian badan hukum dari pendapat para sarjana. E.M. Maijers dikutip Chidir Ali mengatakan bahwa badan hukum meliputi sesuatu yang menjadi pendukung hak dan kewajiban. Sementara itu Logemann sebagaimana juga dikutip Chidir Ali memberikan pengertian badan hukum adalah personifikasi yaitu suatu perwujudan atau penjelasan hak dan kewajiban (Ali, 2014). Menurut E. Utrecht badan hukum adalah setiap pendukung hak yang tidak berjiwa yang bukan manusia, badan hukum sebagai gejala sosial adalah suatu gejala yang riil dalam pergaulan hukum yaitu sesuatu yang dapat dicatat dalam pergaulan hukum biarpun tidak berwujud manusia atau benda yang dibuat dari besi, batu, dan sebagainya. Yang menjadi penting bagi pergaulan hukum adalah badan hukum mempunyai suatu kekayaan yang sama sekali terpisah dari kekayaan anggotanya (Utrecht,1983).
Rochmat

Soemitro mengemukakan bahwa badan hukum ialah suatu badan yang dapat mempunyai harta hak serta kewajiban seperti orang pribadi (Soemitro, 1993). Lebih lengkap dari pendapat Rochmat Soemitro, R. Soebekti menyatakan bahwa badan hukum pada pokoknya adalah suatu badan atau perkumpulan yang dapat memiliki hak-hak dan melakukan perbuatan seperti seorang manusia serta memiliki kekayaan sendiri, dapat menggugat dan digugat di depan pengadilan (Widjaja, 2005). Pendapat yang lebih lengkap dikemukakan oleh Soedikno Mertokusumo bahwa badan hukum adalah organisasi atau kelompok manusia yang mempunyai tujuan tertentu yang dapat menyandang hak dan kewajiban. Negara dan Perseroan Terbatas misalnya adalah organisasi atau kelompok yang merupakan badan hukum. Selanjutnya dikatakan Soedikno Mertokusumo badan hukum itu bertindak sebagai suatu kesatuan dalam lalu lintas hukum seperti orang, hukum menciptakan badan hukum oleh karena pengakuan organisasi atau kelompok manusia sebagai subyek hukum itu sangat diperlukan karena bermanfaat bagi lalu lintas hokum (Mertokusumo, 2005).

Berdasarkan pendapatpendapat para sarjana dapat disimpulkan bahwa badan hukum sebagai subyek hukum memiliki unsur-unsur, perkumpulan orang (organisasi) dapat melakukan perbuatan hukum dalam hubunganhubungan hukum, mempunyai harta kekayaan sendiri, mempunyai pengurus, mempunyai hak dan kewajiban, dan dapat digugat dan menggugat di depan pengadilan. Menurut doktrin ajaran umum badan hukum untuk memenuhi 
kriteria sebagai subyek hukum badan hukum memerlukan kriteria adanya kekayaan yang terpisah, mempunyai tujuan tertentu, mempunyai kepetingan sendiri, dan adanya organisasi yang teratur (Rido, 2004).

Harta dimaksud dari pemasukan para anggota atau dari suatu anggota atau dari suatu perbuatan pemisahan kekayaan dari seseorang yang digunakan untuk suatu tujuan tertentu, dengan demikian harta kekayaan tersebut menjadi obyek tuntutan tersendiri dari pihak-pihak ketiga yang mengadakan hubungan hukum dengan badan hukum tersebut. Badan hukum mempunyai pertanggungjawaban tersendiri, kekayaan yang terpisah membawa akibat; kreditur pribadi para anggota tidak mempunyai hak menuntut harta kekayaan badan hukum, para anggota secara pribadi tidak dapat menagih piutang dari badan hukum terhadap pihak ketiga, kompensasi antara utang pribadi dan utang badan hukum tidak diperkenankan, hubungan hukum baik perjanjian, maupun proses-proses antara anggota dan badan hukum mungkin saja seperti halnya antara badan hukum dengan pihak ketiga, pada kepailitan hanya kreditur badan hukum yang dapat menuntut harta kekayaan terpisah itu;

1. Mempunyai tujuan tertentu Tujuan tertentu tersebut bukanlah tujuan pribadi dari suatu anggota melainkan tujuan dari badan hukum itu sendiri sebagai subyek hukum, karena badan hukum hanya dapat bertindak dengan perantara organnya perumusan tujuan dan kehendaknya tegas dan jelas. Ketegasan ini memudahkan pemisahan apakah organ bertindak dalam batas-batas wewenangnya atau tidak, bagi kita di Indonesia, bahwa tujuan itu hendaknya mencerminkan nilai-nilai etika, dengan keadilan hukum berdasarkan Pancasila tidak bertentangan dengan undangundang, kesusilaan dan ketertiban umum, harus betulbetul mencerminkan keadilan masyarakat Pancasila;

2. Mempunyai kepentingan sendiri

Kepentingan yang dimaksud adalah merupakan hak-hak subyektif sebagai akibat dari peristiwa-peristiwa hukum, kepentingan itu dilindungi oleh hukum, badan hukum yang memiliki kepentingan itu, dapat menuntut dan mempertahankan kepentingan itu terhadap pihak ketiga dalam pergaulan hukum;

3. Adanya organisasi yang teratur

Badan hukum adalah suatu konstruksi hukum, dalam pergaulan hukum badan hukum diterima sebagai subyek hukum selain manusia. Badan hukum hanya dapat bertindak hukum dengan perantara organnya, organ, pembagian tugas, tindakan hukum dapat dilakukan, pemilihannya diatur dalam anggaran dasar dan peraturan atau keputusan rapat anggota, kesemuanya inilah mewujudkan adanya perwujudan dari sebuah organisasi yang teratur.

Empat syarat sebagai kriteria suatu badan hukum menurut doktrin sesuai dengan filosofi pendirian badan hukum sebagaimana dikemukakan oleh 
Nindyo Pramono, bahwa filosofi orang mendirikan badan hukum adalah bahwa dengan kematian pendirinya maka harta kekayaannya diharapkan masih dapat bermanfaat bagi orang lain. Oleh karena alasan filosofi itu hukum menciptakan suatu kreasi sesuatu yang oleh hukum kemudian dianggap diakui sebagai subyek hukum yang mandiri seperti halnya orang, kemudian sesuatu itu oleh ilmu hukum disebut sebagai badan hukum yang dapat menjadi subyek hukum dan menyandang hak dan kewajiban. Agar badan hukum itu dapat bertindak seperti halnya orang sungguhan maka diperlukan organ sebagai alat dari badan hukum itu menjalin hubungan hukum dengan pihak ketiga agar badan hukum itu dapat berinteraksi dalam pergaulan hukum seperti membuat perjanjian, melakukan kegiatan usaha tertentu diperlukan modal, modal awal dari badan hukum itu datang dari kekayaan si pendiri yang dipisahkan, menjadi kekayaan badan hukum itu, terpisah, terlepas dari kekayaan si pendiri (Pramono, 2007).

Pembahasan

Badan Hukum Publik dan Badan Hukum Privat

L.J van Apeldoorn mengolongkan badan hukum menjadi dua yaitu:

1. Persekutuan manusia yang bertindak dalam pergaulan hukum seolah-olah sebagai purusa tunggal,

2. Harta dengan tujuan yang tertentu tetapi dengan tiada yang empunya dalam pergaulan hukum diperlakukan sebagai purusa (yayasan),

Selanjutnya persekutuan manusia dikelompokkan menjadi tiga yaitu:
1. Perhimpunan yaitu persekutuan-persekutuan yang hidupnya timbul dari penggabungan diri secara suka rela dari purusa-purusa pribadi yang didirikan oleh purusa pribadi dan bersandar pada perjanjian.

2. Persekutuan-persekutuan yang tidak didirikan oleh puruspurusa khusus melainkan tumbuh secara historis, seperti negara, provinsi, kota praja, dan sebagainya.

3. Persekutuan-persekutuan yang didirikan oleh kekuasaan umum (Apeldorn, 1996).

E. Utrecht menggolongkan badan hukum berdasarkan kriteria pergaulan hukum, aneka warna hukum dan pembagian hukum dalam hukum publik dan hukum privat (Utrecht, 1983). Berdasarkan pergaulan hukum ada bermacammacam badan hukum:

1. Perhimpunan (verenigingen) yang dibentuk dengan sengaja dan dengan suka rela oleh orang yang bermaksud memperkuat kedudukan ekonomi mereka, memelihara kebudayaan, mengurus soalsoal sosial dan sebagainya. Badan hukum semacam misalnya Perseroan Terbatas, perhimpunan yang didirikan berdasarkan peraturan LNHB $1939 \mathrm{Nr} 717$ (badan hukum Indonesia), perhimpunan yang didirikan berdasarkan peraturan LNHB $1870 \mathrm{Nr} 64$ (badan hukum Eropah, dan Perusahaan Negara).

2. Persekutuan orang (gemeenschap van mensen) yang ada karena perkembangan faktor-faktor sosial dan politik dalam sejarah misalnya negara, daerah provinsi, kabupaten, desa. 
3. Organisasi yang didirikan berdasarkan undang-undang tetapi bukan perhimpunan.

4. Yayasan yaitu tiap kekayaan yang tidak merupakan kekayaan orang atau kekayaan badan yang diberi tujuan tertentu.

Sementara itu berdasarkan aneka warna hukum yang mengacu pada Pasal 163 I.S (Indische Staatsregeling) yang membagi penduduk dalam tiga golongan yaitu golongan Eropa, Timur Asing, Bumiputera dan Pasal 131 I.S. (Indische Staatsregeling) yang mengatur tentang hukum yang berlaku bagi masing-masing golongan, yaitu bagi golongan Eropa dan yang dipersamakan berlaku Hukum Perdata dan Hukum Dagang Barat berdasarkan asas konkordansi, bagi golongan Timur Asing berlaku hukum mereka masing-masing, bagi golongan Bumiputera dan yang dipersamakan berlaku hukum adat mereka, dengan catatan bahwa golongan Timur Asing dan Bumiputra diperbolehkan untuk menundukkan diri kepada Hukum Eropa/Barat. Berdasarkan aneka warna hukum terdapat tiga macam badan hukum:

1. Badan hukum menurut hukum Eropa yaitu badan hukum yang diatur menurut hukum yang dikonkordansikan dengan hukum yang berlaku di Negeri Belanda;

2. Badan hukum menurut hukum bukan Eropa yang tertulis sekarang badan hukum menurut hukum Indonesia yaitu badan hukum yang didirikan oleh Timur Asing atau Bumiputera yang menundukkan diri dengan hukum Negeri Belanda;

3. Badan Hukum adat adalah badan hukum menurut hukum
Bumi Putera yang pada umumnya tidak tertulis.

Selanjutnya disebutkan oleh E. Utrecht berdasarkan pembagian hukum dalam hukum publik dan hukum privat, badan hukum dapat dibagi menjadi dua:

1. Badan hukum publik,

2. Badan hukum privat.

Dengan merujuk pendapat E. Utrecht di atas penggolongan badan hukum publik dan badan hukum privat didasarkan pada kriteria pembagian hukum yaitu hukum publik dan hukum privat. Tidak dijelaskan lebih lanjut tentang apakah yang di maksud badan hukum publik dan badan hukum privat berdasarkan kriteria pembagian hukum publik dan hukum privat. Terhadap penggolongan badan hukum publik dan badan hukum privat ini menimbulkan beberapa pertanyaan diantaranya apakah yang dimaksud badan hukum publik dan badan hukum privat dan apakah perbedaan antara badan hukum publik dan badan hukum privat.

Sepanjang pengetahuan peneliti dalam berbagai Peraturan Perundang-undangan yang berhubungan dengan badan hukum tidak dapat ditemukan suatu pengertian, definisi, atau batasan dan penggolongan tentang badan hukum publik dan badan hukum privat. Adapun yang dapat ditemukan adalah istilah badan hukum publik dan hukum privat sebagaimana terdapat dalam Undang-Undang Nomor 24 Tahun 2003 tentang Mahkamah Konstitusi Pasal 51 ayat (1) c yang menyebutkan "badan hukum publik atau privat dapat menjadi pemohon sebagai pihak yang menganggap hak dan/atau kewenangan konstitusionalnya 
dirugikan oleh berlakunya undangundang".

Secara gramatikal tidak ada penyebutan istilah badan hukum publik dan badan hukum privat dalam KUHPerdata. Menurut R. Ali Rido Ketentuan Pasal 1653 KUHPerdata mengatur baik badan hukum publik maupun badan hukum privat, dalam Pasal 1653 KUHPerdata sebagai peraturan umum menyebutkan ada 3 (tiga) macam perkumpulan (badan hukum) yaitu:

a. Perkumpulan yang diadakan oleh kekuasaan umum;

b. Perkumpulan yang diakui oleh kekuasaan umum;

c. Perkumpulan yang diperkenankan atau untuk suatu maksud tertentu yang tidak berlawanan dengan undang-undang atau kesusilaan (Rido, 2004).

Peter Mahmud Marzuki (2008) menyatakan badan hukum publik adalah negara dan bagian-bagian negara seperti daerah kota dan lainlain, sedangkan badan hukum privat adalah suatu organisasi yang bergerak diluar bidang politik dan kenegaraan, badan hukum privat didirikan untuk mencari keuntungan atau untuk tujuan sosial. Memperhatikan pendapat Peter Mahmud Marzuki bahwa kriteria yang digunakan untuk membedakan badan hukum publik dan badan hukum privat masih bersifat umum, pembedaan ini belum menjawab pertanyaan seperti bagaimanakah halnya kalau negara atau bagian dari negara mendirikan atau ikut serta dalam organisasiorganisasi di luar organisasi negara untuk tujuan seperti untuk mencari keuntungan.

Man. S. Sastra Widjaja (2005) memberikan kriteria untuk menentukan apakah suatu badan hukum itu merupakan badan hukum publik dan badan hukum privat (disebut badan hukum perdata) yaitu:

1. Berdasarkan terjadinya, atau berdasarkan pendirinya, artinya apabila badan hukum tersebut untuk pendiriannya berlaku ketentuan hukum publik atau didirikan oleh kekuasaan umum badan hukum tersebut merupakan badan hukum publik, akan tetapi apabila badan hukum didirikan oleh orang perorangan sehingga terhadapnya berlaku ketentuan hukum perdata badan hukum tersebut termasuk badan hukum privat;

2. Lapangan Pekerjaan, artinya apabila lapangan pekerjaan dari badan hukum itu untuk kepentingan umum termasuk badan hukum publik, apabila lapangan pekerjaan untuk kepentingan orang perseorangan atau Sekelompok orang saja termasuk badan hukum privat (Widjaja, 2005).

Pembedaan badan hukum publik dan badan hukum privat berdasarkan kriteria dari Man. S. Sastra Widjaja ini belum menjawab pertanyaan bagaimanakah halnya dengan badan hukum yang didirikan oleh kekuasaan umum atau negara yang lapangan pekerjaannya bukan untuk kepentingan umum tetapi untuk tujuan tertentu seperti mencari keuntungan. Untuk menjawab pertanyaan-pertanyaan terhadap pendapat-pendapat tentang pengertian dan perbedaan antara hukum badan hukum publik dengan badan hukum privat seperti yang telah diuraikan di atas, relevan untuk mengutip pendapat dari R. Ali Rido dan para kalangan sarjana Jerman. R. Ali Rido menyatakan jika 
badan hukum yang diadakan oleh kekuasaan umum itu mempunyai wewenang publik badan hukum itu merupakan badan hukum publik, jadi tidak semua badan hukum yang diadakan oleh kekuasaan umum itu badan hukum publik, dapat pula merupakan badan hukum privat, kriterianya ialah dalam hal wewenangnya badan hukum itu (Rido, 2004). Menurut pendapat para kalangan sarjana Jerman bahwa kriteria untuk membedakan badan hukum publik dengan badan hukum privat adalah kekuasaan sebagai penguasa, yaitu badan hukum publik adalah badan hukum yang mempunyai kekuasaan sebagai penguasa artinya dapat mengambil keputusankeputusan dan membuat peraturanperaturan yang mengikat orang lain yang tidak tergabung dalam badan hukum tersebut (Ali, 2014). Dengan demikian badan hukum privat adalah tidak mempunyai kekuasaan sebagai penguasa.

Menurut peneliti pendapat dari R. Ali Rido dan para kalangan sarjana Jerman di atas berkaitan dengan pendapat dari E. Utrecht yang menggolongkan badan hukum publik dan badan hukum privat. Berdasarkan pembagian hukum dalam hukum publik dan hukum privat dalam rangka mendapatkan penjelasan lebih lanjut perbedaan antara badan hukum publik dan badan hukum privat, untuk itu dibahas lebih lanjut tentang pembagian atau pembidangan hukum dalam hukum publik dan hukum privat. Dalam buku Pengantar Ilmu Hukum dari E. Utrecht disebutkan menurut isinya hukum dibagi dalam dua golongan yaitu hukum publik dan hukum privat (Utrecht, 1983). Pembagian ke dalam dua golongan ini dikenal oleh negara-negara Eropa
Kontinental setelah mereka mengenal hukum Romawi yang kemudian meresapinya, yang sebelumnya masih berpegangan pada hukum kebiasaan dimana pembagian hukum publik dan hukum perdata tidak dikenal (Hartono, 1982).

Ulpianus adalah ahli hukum Romawi yang membagi hukum dalam dua golongan menyatakan "Publicum ius est, quod ad statum rei romance spectat privatum quod ad singulorum utitilatem; sunt enim quaedam publice utilia quaedam privatim". Hukum publik adalah hukum yang berhubungan dengan kesejahteraan Romawi, hukum perdata adalah hukum yang mengatur kepentingan orang secara khusus, karena ada hal yang merupakan kepentingan umum, ada pula hal yang merupakan kepentingan perdata. J.A. Loeff sebagaimana dikutip E. Utrecht memberikan kriteria yang digunakan untuk membedakan hukum publik dengan hukum privat adalah subyek dalam suatu hubungan hukum publik mengatur hubungan antara negara dengan warganya sedangkan hukum privat mengatur hubungan antara individu (Hartono, 1982). Kelemahan dari pendapat ini adalah berkaitan dengan pertanyaan tentang bagaimanakah halnya dalam hubungan privat yang dilakukan oleh negara dengan orang perorangan/swasta misalnya negara/pemerintah mengadakan perjanjian sewa menyewa dengan seseorang untuk tujuan tertentu semisal untuk mendirikan kantor, dengan kriteria yang digunakan oleh J.A. Loeff berarti sewa menyewa tersebut masuk ke dalam pengertian hukum publik padahal sebenarnya hubungan sewa 
menyewa adalah hubungan yang diatur oleh hukum privat.

L.J. van Apeldoorn (1996) mengatakan pembagian hukum publik dan hukum privat didasarkan pada kepentingankepentingan yang diatur oleh isi dari peraturan hukum, hukum publik mengatur kepentingan umum atau publik dan hukum privat mengatur kepentingan khusus atau perdata. Titik lemah dari pendapat ini adalah berkaitan dengan ditemukan peraturan hukum yang termasuk hukum privat yang mengatur kepentingan umum. Contoh dalam hukum perkawinan merupakan hubungan antara dua orang yang masuk dalam hukum privat, tetapi hukum perkawinan juga mengatur perkawinan harus dicatatkan/dikukuhkan di depan petugas catatan sipil/pemerintah yang termasuk dalam wilayah hukum publik. Sebaliknya peraturan hukum yang termasuk dalam hukum publik yang mengatur kepentingan privat misalnya undang-undang kewarganegaraan yang mengatur naturalisasi yang merupakan kepentingan khusus/perdata dari yang dinaturalisasi.

Paul Scholten membedakan hukum publik dengan hukum privat berdasarkan asas-asas yang menjadi dasar dari masing-masing, hukum privat adalah hukum biasa karena memuat asas-asas umum, negara juga tunduk dengan sepanjang tidak diadakan perkecualian. Selanjutnya dikatakan Paul Scholten perkecualian tersebut terdapat dalam hukum publik dan menjadi hukum istimewa, hukum publik membatasi kekuasaan hukum privat tetapi tidak meniadakan hukum privat (Soekanto I, 1979). Sementara itu dilihat dari pembentukan norma-norma hukum publik, Maria Farida dalam bukunya yang berjudul Ilmu Perundang-Undangan 1 (Satu) yang mengutip pendapat Benyamin Akzin dalam bukunya yang berjudul Law, State, and International Legal Order mengemukakan bahwa dalam pembentukan norma-norma hukum publik berbeda dengan norma-norma hukum privat, jika dilihat pada stuktur norma (Norm Structure), hukum publik berada di atas hukum privat sedangkan jika dilihat dari stuktur lembaga maka lembaga-lembaga negara (Public Authorities) terletak di atas masyarakat (Population) (Farida, 2007). Dalam pembentukannya, norma-norma hukum publik itu dibentuk oleh lembaga negara (penguasa negara, wakil-wakil rakyat) atau dapat disebut sebagai supra struktur, sehingga terlihat jelas bahwa norma-norma hukum yang ditetapkan oleh lembagalembaga negara mempunyai kedudukan lebih tinggi daripada norma hukum yang dibentuk oleh masyarakat atau dapat disebut sebagai infra struktur, oleh karena itu norma hukum publik itu dibentuk oleh lembaga-lembaga negara, maka dalam pembentukannya pun harus dilaksanakan secara berhati-hati, karena norma hukum publik harus dapat memenuhi kehendak serta keinginan masyarakat, berbeda dengan dengan pembentukan noram-norma hukum privat (Aksin, 1964). Norma-norma dalam hukum privat itu biasanya selalu sesuai dengan kehendak/keinginan masyarakat oleh karena hukum privat ini dibentuk oleh masyarakat yang bersangkutan dengan perjanjian atau transaksi yang bersifat perdata, sehingga masyarakat dapat merasakan 
sendiri apakah norma hukum yang terdapat dalam perjanjian atau transaksi tersebut sudah sesuai dengan kehendak/keinginan masyarakat atau tidak.

Menurut pendapat van Praag dalam membedakan hukum publik dan hukum privat adalah bahwa dalam hukum publik tidak mungkin berlaku hukum privat, sesungguhnya hukum privat tersebut adalah hukum yang belaku umum untuk orang perorangan maupun badan privat. Begitupun tehadap badan hukum publik, hukum publik justru berlaku secara khusus untuk badan hukum publik, hanya dalam keadaan tertentulah dapat ditiadakan berlakunya hukum privat terhadap hukum publik hingga semata-mata dalam keadaan itu berlaku hukum publik. Dalam keadaan bagaimana hingga berlakunya hukum privat dikesampingkan, hal ini ditentukan oleh hukum positif, hukum positif akan menentukan bila terhadap suatu perbuatan tertentu yang harus dilakukan oleh badan hukum publik tersebut menyangkut kepentingan yang lebih luas (Prasetya, 2001).

Pendapat-pendapat tentang hukum publik dan hukum privat di atas telah menunjukkan dasar pembagian hukum publik dan hukum privat ini telah menjadi perdebatan para ahli hukum, bahkan ada sarjana yang berpendapat tidak ada pemisahan antara hukum publik dan hukum privat seperti Hans Kelsen dengan Stufentheori-nya dan Kranenburg. Menurut Hans Kelsen semua kaidah hukum diturunkan dari satu kaidah tertinggi/groundnorm baik badanbadan Pemerintah maupun swasta membuat petunjuk-petunjuk yang diturunkan dari kaidah-kaidah tertinggi dengan demikian pembagian hukum publik dan hukum privat merupakan pembagian sewenang-wenangan (Hartono I, 1982). Sementara itu Kranenburg berpendapat bahwa jika kepentingan umum dan kepentingan perorangan dipakai sebagai dasar pembagian hukum dalam hukum publik dan hukum perdata maka kacaulah gambargambar yang kita peroleh tentang pembagian tersebut.

Terhadap

perdebatanperdebatan yang berkaitan dengan pembagian hukum publik dan hukum privat, Soedikno Mertokusumo mengatakan pembagian hukum publik dan hukum privat merupakan pembagian klasik meskipun banyak diperdebatkan tetapi sampai sekarang masih digunakan (Mertokusumo I, 2005). Sampai saat sekarang masih relevan untuk membuat perbedaan antara hukum publik dan hukum privat walaupun dalam hal-hal tertentu batas-batas antara hukum publik dan hukum privat menjadi kabur. Sebagaimana yang dikemukan N.E Algra bahwa hingga kini kita telah memberikan beberapa perbedaan penting antara hukum publik dan hukum privat, namun suatu batas tidaklah dapat diberikan ada daerah peralihan dimana sukar untuk memberikan tanda ini atau tanda itu (Algra, et. al, 1983).

Menurut N.E. Algra sepanjang tidak mengenai antar lembaga negara ciri khasnya yang penting dalam hukum publik adalah hubungan hukum antara negara/pemerintah dengan warga negara itu ditetapkan secara sepihak oleh Pemerintah, warga negara terikat secara yuridis pada keputusan pemerintah seperti penetapan pajak, ijin mendirikan bangunan. Sementara itu dalam 
hukum privat yang menjadi ciri khasnya adalah asas pokok otonomi para pihak/warganegara, artinya para pihak boleh mengatur sendiri menurut pandangannya hubungan satu sama lain seperti kebebasan membuat perjanjian, testament, milik pribadi. Konsekuensi dari ciri khas yang ada pada masing-masing ini dalam hukum publik mempertahankan hak pada umumnya ada ditangan pemerintah misalnya pembongkaran bangunan tanpa ijin dan penentuan tuntutan pidana ada pada jaksa konsekuensinya pada hukum publik ini inisiatif untuk meminta perlindungan hukum ada pada warga negara. Pada hukum privat dalam terjadinya perselisihan hak untuk mempertahankan atau tidak mempertahankan haknya ada pada para pihak itu sendiri untuk diajukan kepengadilan bahkan dalam hukum privat para pihak dapat menyetujui penyelesaian perselisihan diserahkan kepada pihak lain selain pengadilan seperti mediasi dan arbitrase (Algra, et. al, 1983).

Menurut

Soedikno

Mertokusumo, hukum publik lazimnya dirumuskan sebagai hukum yang mengatur hubungan penguasa dengan warga negaranya, hukum publik ini adalah keseluruhan peraturan yang merupakan dasar negara untuk mengatur pula bagaimana caranya negara melaksanakan tugasnya, jadi merupakan perlindungan kepentingan negara oleh karena memperhatikan kepentingan umum maka pelaksanaan peraturan hukum publik dilakukan oleh penguasa. Sedangkan hukum privat adalah hukum antar perorangan yang mengatur hak dan kewajiban perorangan yang satu terhadap yang lainnya dalam pergaulan masyarakat, hukum dalam hubungan keluarga melahirkan dua bidang hukum yaitu hukum orang dan keluarga. Selain hukum dalam pergaulan masyarakat melahirkan hukum benda dan hukum perikatan, masih ada bidang hukum perdata lain yaitu hukum waris yang mengandung unsur keluarga dan hukum benda. Jadi bidang hukum privat meliputi hukum tentang orang, hukum keluarga, hukum benda, hukum perikatan dan hukum waris, pelaksanaannya diserahkan pada masing-masing (Mertokusumo III, 2005). Selanjutnya dikatakan terdapat beberapa tolak ukur yang digunakan untuk membedakan antara hukum publik dan hukum privat dalam hukum publik salah satu pihak adalah penguasa dalam hukum privat para pihaknya adalah perorangan tanpa menutup kemungkinan bahwa dalam hukum privat penguasa bisa menjadi pihak, peraturan hukum publik bersifat memaksa sedangkan peraturan hukum privat bersifat melengkapi meskipun ada juga yang memaksa.

Berdasarkan pendapat N.E. Algra (1983) dan Soedikno Mertokusumo di atas beberapa kriteria atau ciri khas yang dapat digunakan untuk membedakan hukum publik dan hukum privat adalah:

a. Dalam hukum publik: hubungan hukum berupa tindakan yang ditetapkan secara sepihak, tindakan sepihak itu oleh subyek sebagai penguasa terhadap warga negara/perorangan, inisiatif mempertahankan hak atau penegakan hukumnya oleh penguasa, hukumnya bersifat memaksa.

b. Dalam hukum privat: hubungan hukum didasarkan pada asas 
otonomi kebebasan para pihak/subyek yang kedudukannya sejajar, subyeknya antar perorangan atau penguasa/pemerintah bisa menjadi subyek inisiatif mempertahankan haknya oleh para pihak sendiri, hukumnya bersifat melengkapi/tidak memaksa walaupun ada juga yang memaksa.

Tabel Kriteria Klasifikasi Badan Hukum Publik dan Hukum Privat

\begin{tabular}{|c|l|l|l|}
\hline $\begin{array}{c}\text { N } \\
\text { o }\end{array}$ & \multicolumn{1}{|c|}{ Kriteria } & \multicolumn{1}{c|}{ Hukum Publik } & \multicolumn{1}{c|}{ Hukum Privat } \\
\hline 1. & Subyek/Pihak & Pemerintah/Individu & $\begin{array}{l}\text { Individu/IndividuPemerin } \\
\text { tah }\end{array}$ \\
\hline 2. & $\begin{array}{l}\text { Hubungan } \\
\text { Hukum }\end{array}$ & $\begin{array}{l}\text { Vertikal/ Sepihak } \\
\text { antara Negara dengan } \\
\text { Individu }\end{array}$ & $\begin{array}{l}\text { Otonom/horizontal antara } \\
\text { Individu dengan Individu }\end{array}$ \\
\hline 3. & Sifat Norma & Memaksa & Tidak memaksa/memaksa \\
\hline 4. & Konsekuensi & $\begin{array}{l}\text { Lapangan Hukum } \\
\text { Publik }\end{array}$ & Lapangan Hukum Privat \\
\hline
\end{tabular}

Dari kriteria yang telah disebutkan di atas dalam kaitannya mengenai penggolongan badan hukum publik dan badan hukum privat berdasarkan pembidangan hukum publik dan hukum privat, badan hukum privat adalah badan hukum yang ada dalam lapangan hukum privat dapat berupa badan hukum yang didirikan oleh perorangan, didirikan oleh negara atau negara sendiri yang bertindak sejajar dan otonom dengan segala konsekuensinya dalam lapangan hukum privat. Sementara badan hukum publik adalah badan hukum yang bertindak secara vertikal dan sepihak dengan segala konsekuensi dalam wilayah hukum publik.

Negara/Pemerintah dimungkinkan berkedudukan sebagai subyek dalam hukum privat, menurut N.E. Algra disebabkan oleh karena terjadinya perubahan pandangan politik atas tugas negara dari Negara Penjaga Malam menjadi Negara Pemelihara
Sosial atau Negara Kesejahteraan yang berbarengan dengan pergeseran atau perubahan dari hukum privat ke hukum publik. Perubahan ini selanjutnya membawa konsekuensi Pemerintah melalui jalan hukum privat juga memperhatikan berbagai macam tugas misalnya membuat perjanjian, memberikan tanah, mendirikan atau mengambil bagian dalam perseroan atau yayasan. Sebaliknya ada juga berbagai organisasi hukum privat yang diserahi tugas dan wewenang publik, contohnya di Belanda terdapat perusahaan di bidang pertanggungan sosial, yang menurut bentuknya merupakan perkumpulan hukum privat tetapi berdasarkan tugas dan wewenangnya merupakan badan hukum publik.

Dalam beberapa ketentuan Peraturan Perundang-undangan di Indonesia ditemukan ketentuan bahwa terhadap badan hukum atau organisasi yang berbentuk privat 
diberi wewenang publik, sebagaimana disebutkan UndangUndang Nomor 37 Tahun 2008 tentang Ombudsman Republik Indonesia, Pasal 6 Undang-Undang Nomor 37 Tahun 2008 tentang Ombudsman Republik Indonesia (selanjutnya disebut UU Ombudsman) menyatakan: Ombudsman berfungsi mengawasi penyelenggaraan pelayanan publik yang diselenggarakan oleh Penyelenggara Negara dan pemerintahan baik di pusat maupun di daerah termasuk yang diselenggarakan oleh Badan Usaha Milik Negara serta Badan Swasta atau Perseorangan yang diberi tugas menyelenggarakan pelayanan publik tertentu, selanjutnya dalam Undang-Undang Nomor 25 Tahun 2009 tentang Pelayanan Publik (selanjutnya disebut UU Pelayanan Publik) Pasal 1 angka 2 yang menyatakan: Penyelenggara pelayanan publik yang selanjutnya disebut Penyelenggara adalah setiap institusi penyelenggara negara, korporasi, lembaga independen yang dibentuk berdasarkan undangundang untuk kegiatan pelayanan publik, dan badan hukum lain yang dibentuk semata-mata untuk kegiatan pelayanan publik.

Dengan demikian berdasarkan UU Ombudsman dan UU Pelayanan Publik perbedaan antara badan hukum publik dan badan hukum privat adalah dilihat dari tugas dan kewenangan dari badan hukum itu, badan hukum privat dapat diberikan kewenangan dalam penyelenggaraan pelayanan publik. Sebagai perbandingan di Belanda, badan hukum dalam Netherland Burgerlijk Wetboek (NBW) di atur dalam buku 2, tidak ditemukan adanya batasan tentang apakah yang dimaksud dengan badan hukum. Dalam Pasal 1 mengatur tentang badan hukum publik (Public Legal Persons), dalam Pasal 1 ayat (1) ini disebutkan "The State, the Provinces, The Municipalities, The Water Boards and all other bodies to which legislative power has been granted under the Dutch Constitution have legal personality", dalam Pasal 2 disebutkan "Other bodies charged with governmental duties only have legal personality if this results from what has been specified by or pursuant to law", (Dutch Civil Code, Book 2 Legal Persons article 1 point 1 -2).

Berdasarkan Pasal 1 ayat (1) dan Pasal 2 NBW yang dimaksudkan dengan badan hukum publik itu adalah Negara, provinsi, kotaprajakotapraja (kabupaten/kota), The Waterboards dan lembaga lembaga lainnya yang diberi wewenang dalam bidang legislatif (membuat dan mengeluarkan Peraturan Perundang-undangan) berdasarkan Undang-Undang Dasar Belanda. Badan-badan yang juga dapat disebut badan hukum publik adalah badan-badan selain yang disebutkan dalam Pasal 1 yang diberi wewenang dalam rangka tugas-tugas Pemerintah dan hasil yang menjadi tujuan pemberian wewenang tersebut secara spesifik ditentukan atau sesuai dengan hukum. Dengan demikian kriteria yang digunakan untuk menentukan suatu badan sebagai badan hukum publik adalah adanya kewenangan legislatif yang dimiliki badan itu berdasarkan Undang-Undang Dasar Belanda atau badan yang badan tertentu lainnya yang mempunyai atau diberi wewenang dalam rangka melaksanakan tugas-tugas Pemerintahan.

Pada bidang hukum harta kekayaan badan hukum publik sebagai badan hukum, menurut hukum Belanda adalah sama kedudukannya dengan subyek 
hukum orang, badan hukum lembaga-lembaga gereja/lembagalembaga keagamaan, dan badan hukum privat yaitu dapat memiliki segala hak dan kewajiban kecuali Undang-Undang menentukan lain. Sebagaimana disebutkan dalam Pasal 1 ayat (5) buku 2 NBW "As far as it concerns the law of property, a legal person is tantamount (equal) to a natural person, unless the contrary result from law".

Sementara itu badan hukum privat dalam NBW di atur dalam Pasal 3 Private Legal Persons disebutkan "Associations, Cooperatives, Mutual Insurance Societes, Open Corporations, Cloesed Corporation and Foundations have legal personality", badan-badan yang termasuk yang termasuk sebagai badan hukum privat adalah Perkumpulan/Perhimpunan,

Perseroan Terbatas, Perusahan Asuransi Swasta, PT. Terbuka/Public Limited Company, PT. Tertutup/Private Limited Company dan Yayasan. Dengan demikian maka kriteria yang digunakan untuk menentukan suatu badan hukum merupakan badan hukum privat berdasarkan bentuk badan hukum itu, bentukbentuk badan hukum ini adalah badan hukum yang lazimnya mempunyai tujuan tertentu seperti mencari keuntungan atau tujuan sosial berkedudukan sama seperti orang perorangan yang tidak mempunyai kewenangan seperti badan hukum publik.

\section{Simpulan}

Berdasarkan Pasal 1 ayat (1) dan Pasal 2 NBW yang dimaksudkan dengan badan hukum publik itu adalah Negara, provinsi, kotaprajakotapraja (kabupaten/kota), The Waterboards dan lembaga lembaga lainnya yang diberi wewenang dalam bidang legislatif (membuat dan mengeluarkan Peraturan Perundang-undangan) berdasarkan Undang-Undang Dasar Belanda. Badan-badan yang juga dapat disebut badan hukum publik adalah badan-badan selain yang disebutkan dalam Pasal 1 yang diberi wewenang dalam rangka tugas-tugas Pemerintah dan hasil yang menjadi tujuan pemberian wewenang tersebut secara spesifik ditentukan atau sesuai dengan hukum. Dengan demikian kriteria yang digunakan untuk menentukan suatu badan sebagai badan hukum publik adalah adanya kewenangan legislatif yang dimiliki badan itu berdasarkan Undang-Undang Dasar Belanda atau badan yang badan tertentu lainnya yang mempunyai atau diberi wewenang dalam rangka melaksanakan tugas-tugas Pemerintahan. Sementara itu badan hukum privat dalam NBW di atur dalam Pasal 3 Private Legal Persons disebutkan "Associations, Cooperatives, Mutual Insurance Societes, Open Corporations, Cloesed Corporation and Foundations have legal personality", badan-badan yang termasuk yang termasuk sebagai badan hukum privat adalah Perkumpulan/Perhimpunan,

Perseroan Terbatas, Perusahan Asuransi Swasta, PT. Terbuka/Public Limited Company, PT. Tertutup/Private Limited Company dan Yayasan. Dengan demikian maka kriteria yang digunakan untuk menentukan suatu badan hukum merupakan badan hukum privat berdasarkan bentuk badan hukum itu, bentukbentuk badan hukum ini adalah badan hukum yang lazimnya mempunyai tujuan tertentu seperti mencari keuntungan atau tujuan sosial berkedudukan sama seperti orang perorangan yang tidak 
mempunyai kewenangan seperti badan hukum publik.

\section{Daftar Pustaka}

Benyamin Aksin, 1964, Law State, and International Legal Order Essays in Honor of Kelsen, Knoxville, The University of Tennesee Press.

Chidir Ali, 2014, Badan Hukum, Alumni, Bandung.

Dutch Civil Code, Book 2 Legal Persons article 1 point $1-2$, available from ; http:// www.dutchcivilcodebook.htm.

E. Utrecht,1983, Pengantar Dalam Hukum Indonesia, PT Ichtiar Baru, Jakarta.

L.J. van Apeldoorn,1996, Pengantar Ilmu Hukum, Pradnya Paramita, Jakarta.

Man S. Sastra Widjaja, 2005, Bunga Rampai Hukum Dagang, Alumni, Bandung.

Maria Farida, 2007, Ilmu PerundangUndangan 1 (Satu):Jenis, Fungsi dan Materi Muatan, Kanisius, Yogyakarta.

N.E. Algra, et. al, 1983, Mula Hukum Beberapa Bab Mengenai Hukum dan Ilmu untuk Pendidikan Hukum dalam Pengantar Ilmu Hukum, Binacipta, Jakarta.

Nindyo Pramono, 2007, Kekayaan Negara Yang Dipisahkan Menurut UU No 19 Tahun 2003 tentang BUMN, Dalam Permasalahan Seputar Hukum Bisnis : "Persembahan Kepada Sang Maha Guru", Gitama Jaya, Jakarta.

Peter Mahmud Marzuki, 2008, Pengantar Ilmu Hukum,
Kencana Predana Media Group, Jakarta.

Purnadi Purbacaraka dan Soerjono Soekanto,1979, Sendi-Sendi Ilmu Hukum dan Tata Hukum, (Selanjutnya disebut Purnadi Purbacaraka dan Soerjono Soekanto I) Alumni, Bandung.

R. Ali Rido, 2004, Badan Hukum dan Kedudukan Badan Hukum Perseroan, Perkumpulan, Koperasi, Yayasan, Wakaf, Alumni, Bandung.

Rochmat Soemitro, 1993, Hukum Perseroan Terbatas, Yayasan dan Wakaf, PT Eresco, Bandung.

Rudhi Prasetya, 2001, Kedudukan Mandiri Perseroan Terbatas (Disertasi dengan ulasan menurut Undang-Undang No. 1 Tahun 1995 tentang Perseroan Terbatas), (selanjutnya disebut Rudhi Prasetya I), Citra Aditya Bakti, Bandung.

Soedikno Mertokusumo, 2005, Mengenal Hukum Suatu Pengantar, (selanjutnya disebut Soedikno Mertokusumo III) Liberty, Yogyakarta.

Sunarjati Hartono, 1982, Capita Selecta Perbandingan Hukum (Selanjutnya disebut Sunarjati Hartono I), Alumni, Bandung. Undang-Undang Republik Indonesia Nomor 25 Tahun 2009 tentang Pelayanan Publik. Undang-Undang Republik Indonesia Nomor 37 Tahun 2008 tentang Ombudsman Republik Indonesia. 